\title{
Penerapan Model Pembelajaran Kooperatif Tipe Make a Match untuk Meningkatkan Prestasi Belajar Siswa Kelas III A SDN 38 Kota Bengkulu
}

\author{
Akhiri Putri \\ Universitas Bengkulu \\ Akhiriputri978@gmail.com \\ Johanes Sapri \\ Universitas Bengkulu \\ johanesapri@unib.ac.id. \\ Herman Lusa \\ Universitas Bengkulu \\ Hermandatuk1005@gmail.com
}

\begin{abstract}
This study aims to improve student learning achievement in Thematic learning class III A SDN 38 Bengkulu City by applying the Cooperative learning model type Make a Match. The subjects of the study were students of class III A SDN 38 Bengkulu City. The research instruments were observation sheets and test sheets. The observation data analysis technique used the formula of average score, highest score, lowest score, difference in score, and range of values for each criterion. Test data were analyzed using the formula of the average value and the percentage of classical learning completeness. Thus the application of the Make a Match type Cooperative learning model can improve student learning achievement in Thematic learning class III A SDN 38 Bengkulu City.
\end{abstract}

Keywords: Make a Match Model, Learning Achievement, Thematic Learning

\section{Pendahuluan}

Pengembangan karakter dan jati diri bangsa merupakan cita-cita leluhur yang Pembelajaran Tematik adalah pembelajaran yang mengaitkan mata pelajaran-mata pelajaran yang saling terintegrasi yang dikemas ke dalam bentuk tema. Hal ini sesuai dengan pendapat Hidayah dalam jurnalnya (2015:47) pembelajaran Tematik memiliki satu tema yang aktual yang dekat dengan dunia siswa, dan tergambar dalam kehidupan sehari-hari, sehingga menjadi pemersatu materi yang beragam dari mata pelajaran yang ada. Oleh karena itu, guru harus merancang pengalaman belajar yang akan mempengaruhi belajar yang bermakna bagi siswa. Pembelajaran Tematik berpusat pada siswa akan memberi ruang bagi siswa untuk belajar menurut ketertarikan, kemampuan pribadi dan gaya belajar siswa itu sendiri. Muklis dalam jurnalnya (2012:73) menyatakan pembelajaran Tematik merupakan bentuk yang menciptakan sebuah pembelajaran terpadu, yang akan mendorong siswa untuk terlibat dalam belajar, membuat siswa aktif dalam proses pembelajaran 
Putri, A. Sapri, J., Lusa, $\mathrm{H}$.

dan menciptakan situasi pemecahan masalah sesuai dengan kebutuhan siswa, siswa dapat belajar dan bermain dengan kreativitas yang tinggi.

Berdasarkan hasil observasi yang dilakukan pada saat magang II di SDN 38 Kota Bengkulu dari tanggal 10 September sampai dengan 2 November 2020 dan pada saat prapenelitian tanggal 17 Desember 2020, peneliti menemukan permasalahan pada proses pembelajaran di kelas III A yaitu; (1) Guru sudah menerapkan model-model pembelajaran namun belum optimal dalam menyesuaikan model dengan karakteristik siswa. (2) Guru kurang memvariasikan langkah-langkah pembelajaran, seperti belajar sambil bermain yang menyenangkan. (3) Kurangnya semangat siswa dalam belajar sehingga siswa kurang tekun dalam menghadapi tugas dan kurang senang dalam memecahkan soal atau pertanyaan yang disampaikan guru. Pernyataan tersebut sejalan dengan pendapat Hamdani, dkk dalam jurnalnya (2019:44) bahwa tidak adanya rasa nyaman dalam pembelajaran membuat siswa merasa bosan dan kehilangan semangat belajar, hal ini menjadi faktor penghambat bagi siswa untuk mengembangkan intelektual dan pengetahuannya dalam segala hal. (4) Prestasi belajar siswa rendah, hal ini terlihat pada penilaian akhir semester 1 tahun ajaran 2019/2020 di kelas III A, rata-rata nilai kelas pada mata pelajaran Matematika adalah 60 dengan ketuntasan belajar sebesar $44 \%$ (KKM Matematika $\geq 65$ ), dan rata-rata nilai kelas pada mata pelajaran $\mathrm{SBdP}$ adalah 63,3 dengan ketuntasan belajar sebesar 22,2\% (KKM SBdP $\geq 75$ ).

Salah satu model pembelajaran yang dapat diterapkan sebagai solusi terhadap masalah yang ada ialah model pembelajaran Kooperatif tipe Make a Match. Melalui model pembelajaran Kooperatif tipe Make a Match, siswa akan mencari pasangan belajar mengenai suatu konsep atau topik dalam suasana yang menyenangkan, akan melatih siswa untuk memiliki sikap sosial yang baik, dan melatih kemampuan siswa dalam bekerja sama, serta melatih kecepatan berpikir siswa dengan cara mencocokkan kartu berisi soal dan jawaban yang berkaitan dengan materi pembelajaran. Hal tersebut sependapat dengan Rahayu dalam Jurnalnya (2018:106) bahwa, pelaksanaan pembelajaran dengan menerapkan model pembelajaran Kooperatif tipe Make a Match menjadikan siswa lebih aktif dan antusias dalam mengikuti proses pembelajaran, berpikir kritis, dan saling meyakinkan dalam menemukan pasangan kartu yang dianggapnya tepat.

Ketika terjadinya proses menemukan kartu pasangan, maka akan menciptakan adanya interaksi antar anggota kelompok yang lebih tahu dan yang kurang tahu. Anggota kelompok yang lebih tahu dapat membantu proses belajar kelompok anggota yang lain, hal ini sesuai dengan pendapat Taufiq (2012:2.30) bahwa "di usia 8-10 tahun pengaruh kelompok teman sebaya sudah jauh lebih kuat, di mana anak akan menerima dan mengikuti pola-pola yang ditetapkan kelompoknya".

Model pembelajaran Kooperatif tipe Make a Match ini dapat meningkatkan prestasi belajar siswa, hal itu dibuktikan oleh Banun (2019) dalam penelitiannya yaitu rata-rata kelas pada siklus I adalah 85 dan pada siklus II adalah 88, berdasarkan hal tersebut disimpulkan bahwa model pembelajaran Make a Match dapat meningkatkan prestasi belajar IPA materi Benda dan Sifatnya bagi siswa kelas I Semester 2 tahun pelajaran 2017/2018 di SDN 2 Ngadirejo, Kecamatan Pogalan, Kabupaten Trenggalek. Selain itu, Hasil penelitian Desy (2016) bahwa penerapan model kooperatif tipe Make a Match dapat meningkatkan prestasi belajar IPS siswa kelas V SD Negeri 2 Sanden. Hal tersebut ditunjukkan dari adanya peningkatan nilai rata-rata kelas meningkatkan menjadi 81,29. Peningkatan juga terdapat pada jumlah siswa yang mencapai nilai KKM meningkat sebanyak 24 orang dengan presentase sebesar $82,75 \%$.

Penelitian yang dilakukan oleh Banun dan Desy di atas telah membuktikan bahwa, model pembelajaran Kooperatif tipe Make a Match dapat meningkatkan prestasi belajar siswa, karena tipe ini adalah salah satu tipe model pembelajaran Kooperatif yang sesuai dengan karakteristik siswa usia Sekolah Dasar, yaitu menyukai permainan, menginginkan pembelajaran yang menyenangkan, serta lebih 
Putri, A. Sapri, J., Lusa, H.

tertarik dalam berlomba untuk menjadi pemenang, mendapatkan hadiah, dan mendapatkan penghargaan.

\section{Metode}

Jenis penelitian ini adalah Penelitian Tindakan Kela. Penelitian ini Metode yang digunakan dalam penelitian ini adalah Penelitian Tindakan Kelas (classroom action research), yaitu penelitian yang bersifat reflektif, ketika pelaksanaannya dilakukan tindakan yang berulang dalam bentuk siklus dengan tujuan untuk memperbaiki dan meningkatkan kualitas serta hasil pembelajaran. Penelitian ini dilakukan pada siswa kelas III A SDN 38 Kota Bengkulu tahun pelajaran 2019/2020. Jumlah siswa kelas III A adalah 27 orang yang terdiri dari 15 siswa laki-laki dan 12 siswa perempuan. Penelitian ini dilaksanakan di SDN 38 Kota Bengkulu, yang beralamat di Jl. Batang Hari No.38, Nusa Indah, Kec. Ratu Agung, Kota Bengkulu, Bengkulu. Penelitian ini bertujuan untuk memperbaiki proses pembelajaran secara klasikal agar prestasi belajar siswa meningkat dari sebelumnya, sehingga hasil penelitian ini nantinya dapat digunakan pada sekolah yang memiliki kemiripan, baik dalam kurikulum, potensi guru, potensi siswa, maupun sarana dan prasarana sekolah.

Instrumen penelitian ini terdiri dari dua yaitu; lembar observasi dan lembar tes. Lembar observasi ini digunakan sebagai lembar observasi penerapan model Make a Match dalam proses pembelajaran untuk melihat bagaimana aktivitas guru dalam proses pembelajaran. Tes digunakan untuk mengukur kemampuan kognitif (pengetahuan) siswa sebagai tindak lanjut dalam proses pembelajaran yang telah dilakukan. Jenis tes yang digunakan dalam penelitian ini adalah tes tertulis. Fungsi tes tertulis ini ialah untuk mengetahui sejauh mana tingkat pencapaian atau pemahaman siswa terhadap materi pelajaran yang sudah diberikan selama proses pembelajaran berlangsung. Analisis data hasil penelitian ini berbasis Penelitian Tindakan Kelas dengan statistik deskriptif yaitu analisis data sederhana. Data observasi digunakan untuk merefleksikan siklus yang telah dilakukan dan diolah secara deskriptif. Penentu nilai untuk tiap kriteria menggunakan persamaan yaitu rata-rata skor, skor tertinggi, skor terendah, selisih skor dan kisaran nilai untuk tiap kriteria. Pada penilaian prestasi belajar (pengetahuan) dihitung rata-rata dan ketuntasan belajar klasikal.

\section{Hasil}

Siklus I

a. Perencanaan Tindakan

Langkah awal yang dilakukan peneliti pada siklus I ini adalah menganalisis pembelajaran dan Kompetensi Dasar (KD) yang kemudian dijabarkan dan dikembangkan menjadi indakator-indikator yang harus dicapai siswa dalam proses pembelajaran. Pada siklus I ini pembelajaran yang disampaikan adalah pembelajaran 1, subtema 3 Energi Alternatif, tema 6 Energi dan perubahannya.

\section{b. Pelaksanaan}

Penelitian tindakan siklus I dilakukan dalam satu kali pertemuan. Siklus I dilaksanakan pada tanggal 18 Februari 2020. Materi pembelajaran Tematik yang dipelajari pada siklus I adalah tentang lama waktu yang dibutuhkan dan unsurunsur karya dekoratif pada mata pelajaran Matematika dan SBdP, dengan menerapkan model pembelajaran Kooperatif tipe Make a Match pada pembelajaran Tematik. Adapun langkah-langkah pelaksanaan model pembelajaran ini antara lain penyampaian materi, pembentukan kelompok, menemukan pasangan, menunjukkan kecocokan kartu, penguatan dan kesimpulan. 
Putri, A. Sapri, J., Lusa, H.

c. Observasi

Hasil observasi penerapan Make a Match diperoleh skor rata-rata sebesar 12,5 dengan kategori cukup, dapat dilihat pada tabel berikut.

Tabel 4.1 Hasil Analisis Data Observasi Penerapan Make a Match Siklus I

\begin{tabular}{ccc}
\hline Aspek yang diamati & Observer 1 & Observer 2 \\
\hline Penyampaian Materi & 2 & 3 \\
\hline Pembentukan kelompok & 2 & 2 \\
\hline Menemukan pasangan & 2 & 2 \\
\hline Menunjukkan kecocokan kartu & 3 & 3 \\
\hline Penguatan & 2 & 2 \\
\hline Kesimpulan & 1 & 1 \\
\hline Jumlah Skor & 12 & 13 \\
\hline Rata-rata & \multicolumn{3}{c}{12,5} \\
\hline Kategori & \multicolumn{3}{c}{ Cukup } \\
\hline
\end{tabular}

Hasil prestasi belajar siswa pada siklus I diperoleh nilai rata-rata kelas pada mata pelajaran Matematika yaitu 65,3 dengan ketuntasan belajar klasikal yaitu sebesar $52 \%$ yang telah memenuhi KKM (KKM Matematika $\geq 65$ ) di mana dari 27 siswa terdapat 14 siswa yang tuntas sedangkan yang belum tuntas berjumlah 13 orang siswa. Pada mata pelajaran SBdP diperoleh nilai rata-rata kelas yaitu 68,5 dengan ketuntasan belajar klasikal yaitu sebesar $48 \%$ yang telah memenuhi KKM (KKM SBdP 275 ) di mana dari 27 siswa, terdapat 13 siswa yang tuntas sedangkan yang belum tuntas berjumlah 14 orang siswa.

\section{d. Refleksi}

Adapun refleksi pada siklus I yaitu; guru memberikan suatu hal yang menarik dan membiasakan kegiatan tanya jawab agar siswa lebih konsentrasi dalam mengikuti proses pembelajaran, dan tidak sibuk dengan kegiatannya sendiri, guru berkeliling ketika proses pembelajaran agar siswa yang berada di belakang memiliki rasa takut, dan juga melontarkan pertanyaan yang tiba-tiba pada siswa yang masih terlihat main-main ketika proses pembelajaran, sehingga siswa akan selalu mencoba sigap ketika guru melontarkan pertanyaan, guru memberikan bimbingan yang merata kepada setiap kelompok, guru mengoptimalkan pemanfataan media pada saat penyampaian materi, dan mengajak siswa agar lebih aktif dalam proses pembelajaran, serta memberikan reward kepada siswa yang mendapatkan nilai tes tertinggi agar siswa yang lain antusias juga untuk menjadi yang terbaik, dan berhasil dalam mengerjakan soal tes yang diberikan.

\section{Siklus II}

a. Perencanaan Tindakan

Langkah awal yang dilakukan peneliti pada siklus I ini adalah menganalisis pembelajaran dan Kompetensi Dasar (KD) yang kemudian dijabarkan dan dikembangkan menjadi indakator-indikator yang harus dicapai siswa dalam proses pembelajaran. Pada siklus I ini pembelajaran yang akan disampaikan adalah pembelajaran 1, subtema 4 Penghematan Energi, tema 6 Energi dan perubahannya.

\section{b. Pelaksanaan}

Penelitian tindakan siklus II dilakukan dalam satu kali pertemuan. Siklus II dilaksanakan pada tanggal 25 Februari 2020. Materi pembelajaran Tematik yang dipelajari pada siklus II adalah tentang teknik potong, lipat dan sambung, dan luas suatu benda pada mata pelajaran SBdP dan mata pelajaran Matematika, dengan menerapakan model pembelajaran Kooperatif tipe Make a Match pada pembelajaran Tematik. 
Putri, A. Sapri, J., Lusa, $\mathrm{H}$.

c. Observasi

Hasil observasi penerapan Make a Match diperoleh skor rata-rata sebesar 16 dengan kategori baik, yang dapat dilihat pada tabel berikut.

Tabel 4.2 Hasil Analisis Data Observasi Penerapan Make a Match Siklus II

\begin{tabular}{ccc}
\hline Aspek yang diamati & Observer 1 & Observer 2 \\
\hline Penyampaian Materi & 3 & 3 \\
\hline Pembentukan kelompok & 2 & 2 \\
\hline Menemukan pasangan & 3 & 3 \\
\hline Menunjukkan kecocokan kartu & 3 & 3 \\
\hline Penguatan & 3 & 2 \\
\hline Kesimpulan & 2 & 16 \\
\hline Jumlah Skor & 16 & 16 \\
\hline Rata-rata & Baik \\
\hline Kategori & \multicolumn{2}{c}{}
\end{tabular}

Hasil analisis data prestasi belajar siswa pada siklus I diperoleh rata-rata kelas mata pelajaran Matematika yaitu 78,2 dengan ketuntasan belajar klasikal yaitu sebesar $81 \%$ telah memenuhi KKM (KKM Matematika $\geq 65$ ) di mana dari 27 orang siswa terdapat 22 siswa yang tuntas, sedangkan yang belum tuntas berjumlah 5 orang siswa. Pada mata pelajaran SBdP diperoleh nilai rata-rata kelas yaitu 84,4 dengan ketuntasan belajar klasikal yaitu sebesar 77,8\% telah memenuhi KKM (KKM SBdP $\geq 75$ ) di mana dari 27 orang siswa terdapat 21 siswa yang tuntas sedangkan yang belum tuntas berjumlah 6 orang siswa.

\section{d. Refleksi}

Refleksi pada siklus II yaitu; guru harus terus mengasah kepercayaan diri siswa melalui sentuhan verbal maupun nonverbal, seperti lebih memberikan kesempatan siswa untuk menjawab pertanyaan dari siswa lain, dan memberikan kepercayaan kepada bahwa siswa mampu menjawab pertanyaan tersebut dengan pendapatnya sendiri.

\section{Pembahasan}

1. Penerapan Model Pembelajaran Make a Match

Berdasarkan permasalahan yang dipaparkan pada latar belakang penelitian ini, maka dilaksanakan penelitian tindakan kelas dengan menggunakan model pembelajaran Kooperatit tipe Make a Match untuk meningkatkan prestasi belajar siswa pada kelas III A SDN 38 Kota Bengkulu. Setelah dilaksanakan penelitian yang berlangsung dalam dua siklus, hasil yang diperoleh yaitu penerapan model pembelajaran Make a Match dapat meningkatkan prestasi belajar siswa. Hal ini dibuktikan dengan adanya peningkatan hasil tes dari siklus I ke siklus II.

Langkah-langkah model pembelajaran Make a Match yang dilakukan yaitu, saat penyampian materi, pada siklus I memperoleh rata-rata baik, dan pada siklus II memperoleh rata-rata baik. Pada tahap ini guru menyajikan materi dengan memanfaatkan media untuk mengaktifkan siswa, siswa diminta mengamati terlebih dahulu media yang disediakan oleh guru, kemudian siswa diajak untuk bertanya jawab mengenai materi melalui media pembelajaran tersebut, setelah melakukan tanya jawab guru menjelaskan bahwa akan belajar menggunakn model Make a Match, pada saat guru menjelaskan tentang Make a Match, siswa terlihat gembira karena sebelumnya mereka belum pernah belajar dengan menggunakan model ini. Kelas pun penuh riuh dan pertanyaan penasaran yang membuat siswa semakin semangat untuk mengikuti pembelajaran. Hal ini sejalan dengan Shoimin (2014:99) yang menyatakan bahwa dengan Make a Match akan menumbuhkan suasana kegembiraan dalam proses pembelajaran. 
Putri, A. Sapri, J., Lusa, H.

Pembentukan kelompok, pada siklus I memperoleh rata-rata cukup, meningkat pada siklus II diperoleh rata-rata baik. Pada tahap ini siswa dibagi menjadi beberapa kelompok (lima kelompok pada siklus I dan enam kelompok pada siklus II) secara heterogen. Setiap siswa pada tiap kelompok akan berpartisipasi dalam menyelesaikan lembar kerja. Saat pembentukan kelompok siswa sangat antusias dalam mengerjakan lembar kerja secara bersama-sama dan membantu satu sama lain. Hal ini sejalan dengan pendapat Shoimin (2014:99) bahwa keunggulan Make a Match adalah menciptakan kerja sama antarsesama siswa terwujud dengan dinamis, dan munculnya dinamika gotong royong yang merata pada seluruh siswa.

Menemukan pasangan, pada siklus I diperoleh rata-rata cukup, meningkat pada siklus II diperoleh rata-rata baik. Pada tahap ini guru membagikan kartu soal dan jawaban kepada siswa, seteah itu siswa dan guru mendiskusikan waktu untuk menemukan pasangan kartu, kemudian setiap pasangan siswa yang telah menemukan pasangan kartunya dipanggil ke depan untuk mempresentasikan kecocokan kartunya. Siswa dengan penuh semangat menemukan pasangan kartu sesuai dengan waktu yang telah ditentukan, dengan demikian siswa akan terlatih untuk disiplin dalam waktu. Sejalan dengan pendapat Hidayat (2019:102-103) yang menyatakan bahwa Make a Match dapat melatih kedisiplinan siswa dalam memanfaatkan waktu.

Menunjukkan kecocokan kartu, pada siklus I diperoleh rata-rata baik, dan dapat dipertahankan pada siklus II dengan rata-rata skor baik. Pada tahap ini pasangan siswa yang telah menemukan pasangan kartunya, diminta untuk mempresentasikan kartu yang diemukan sesuai dengan soal dan jawaban, bagi pasangan siswa yang berhasil mencocokkan kartunya akan diberikan hadiah, hal ini menyebabkan siswa sangat antusias dalam menemukan pasangan kartunya, sehingga siswa sangat senang dalam proses pembelajaran. Hal ini sejalan dengan pendapat Hidayat (2019:102-103) menyatakan bahwa kelebihan Make a Match adalah kegiatan pembelajaran berjalan lebih menyenangkan.

Penguatan, pada siklusI diperoleh rata-rata cukup, meningkat pada siklus II diperoleh rata-rata baik. Pada tahap ini siswa siswa sudah berani menyampaikan pendapat dalam menjelaskan jawaban yang benar ketika jawaban temannya belum benar pada saat menunjukkan kecocokan kartu, sehingga dengan Make a Match ini akan melatih siswa untuk berani berpendapat. Hal ini sejalan dengan pendapat Hidayat (2019:102-103) yang menyatakan bahwa Make a Match dapat melatih mental dan keberanian siswa.

Kesimpulan, pada siklus I diperoleh rata-rata kurang, meningkat pada siklus II diperoleh rata-rata cukup. Pada tahap ini siswa diminta untuk menyampaikan kesimpulan pembelajaran yang telah dilakukan, dan siswa aktif dalam menyampaikan kesimpulan, berarti siswa aktif dalam proses pembelajaran sehingga kesimpulan pembelajaran dapat diketahuinya. Hal ini sejalan dengan pendapat Hidayat (2019:102-103) bahwa kelebihan model pembelajaran Kooperatif tipe Make a Match yaitu meningkatkan aktivitas belajar siswa dari segi kognitif.

\section{Prestasi Belajar}

Hasil tes pada siklus I menunjukkan bahwa nilai rata-rata kelas dan ketuntasan belajar klasikal masih rendah yaitu nilai rata-rata kelas mata pelajaran Matematika adalah 65,3 dengan ketuntasan belajar sebesar 52\% dan nilai rata-rata kelas mata pelajaran SBdP adalah 68,5 dengan katuntasan belajar klasikal sebesar $48 \%$, hal ini disebabkan karena guru belum mampu mengaktifkan siswa dan mengelola kelas, karena siswa tidak mengerti dengan materi pembelajaran namun malu untuk bertanya, sehingga ketika diberikan soal tes, nilai siswa masih banyak yang belum mencapai KKM. Setelah diperbaiki proses pembelajaran pada siklus I, Hasil tes pada siklus II meningkat, yaitu diperoleh nilai rata-rata kelas pada mata pelajaran Matematika 78,2 dengan ketuntasan belajar klasikal sebesar 81\%, dan nilai rata-rata kelas pada mata pelajaran SBdP juga meningkat yaitu 84,4 dengan ketuntasan belajar klasikal sebesar 77,8\%. Hal tersebut juga telah dibuktikan oleh 
Putri, A. Sapri, J., Lusa, H.

Suini (2019:161) dari hasil penelitiannya bahwa penerapan model Make a Match dapat meningkatkan prestasi belajar yaitu pada mata pelajaran PKn siswa kelas V SDN 2 Pitera semester 1 tahun pelajaran 2017/2018. Selain itu Astuti (2016:163) juga membuktikan dari hasil penelitiannya bahwa model pembelajaran Kooperatif Make a Match dapat meningatkan prestasi belajar siswa pada mata pelajaran Matematika (sifat-sifat bangun ruang) kelas V SDN Penambong. Keberhasilan belajar atau prestasi siswa dalam belajar tersebut dipengaruhi oleh banyak faktor yang saling berkaitan baik berasal dari dalam diri siswa itu sendiri maupun dari luar siswa. Hal tersebut sejalan dengan pendapat Sinar (2018:37) bahwa prestasi siswa pada dasarnya dapat dipengaruhi oleh faktor-faktor yang saling berkaitan, baik faktor internal yang berasal dari dalam diri siswa maupun faktor eksternal yang berasal dari luar diri siswa.

\section{Simpulan}

Berdasarkan hasil penelitian yang telah dilakukan sebanyak dua siklus, dengan menerapkan model pembelajaran Kooperatif tipe Make a Match pada pembelajaran Tematik di kelas III A SDN 38 Kota Bengkulu, dapat diambil kesimpulan yaitu penerapan model pembelajaran Kooperatif tipe Make a Match pada pembelajaran Tematik terdiri dari enam langkah yaitu; penyampaian materi. pembagian kelompok, menemukan pasangan kartu, menunjukkan kecocokan kartu, penguatan, dan kesimpulan.

Model pembelajaran Kooperatif tipe Make a Match dapat meningkatkan prestasi belajar siswa pada pembelajaran Tematik. Hal ini ditunjukkan dengan adanya peningkatan nilai rata-rata kelas dan persentase ketuntasan belajar klasikal antara siklus I dan II pada mata pelajaran Matematika dan SBdP. Hasil tes mata pelajaran Matematika siklus I, diperoleh nilai rata-rata kelas yaitu 65,3 dengan ketuntasan belajar klasikal siklus I yaitu 52\% meningkat pada siklus II dengan nilai rata-rata kelas 78,2 dengan ketuntasan belajar yaitu $81 \%$ (KKM $\geq 65)$. Hasil tes mata pelajaran SBdP siklus I, diperoleh nilai rata-rata kelas yaitu 68,5 dengan ketuntasan belajar klasikal yaitu $48 \%$ meningkat pada siklus II dengan nilai rata-rata kelas 84,4 dengan ketuntasan belajar klasikal yaitu $77,8 \%$ (KKM $\geq 75)$.

\section{Saran}

Berdasarkan kesimpulan di atas, ada beberapa saran yang disampaikan peneliti yaitu; saat proses pembelajaran berlangsung, guru disarankan untuk lebih meningkatkan penguasaan pengelolaan kelas, karena ketika guru menguasai dan dapat mengontrol kelas dengan baik maka kegiatan lebih terarah dan berjalan dengan baik, menarik dan menyenangkan. Dalam meningkatkan prestasi belajar Tematik, guru dapat menerapkan model pembelajaran Kooperatif tipe Make a Match, karena yang menarik dalam model ini adalah siswa diajak untuk bermain mencocokkan kartu soal dan jawaban, melalui permainan tersebut siswa akan terdorong dan tertantang untuk berhasil dengan suasana yang menyenangkan.

\section{Referensi}

Astuti, Mahyuni, (2016), Penerapan Model Pembelajaran Kooperatif Make a Match pada Materi Sifat-Sifat Bangun Ruang untuk Meningkatkan Respon dan Prestasi Belajar Siswa Kelas V SDN Penambong, Jurnal Kependidikan, eISSN: 2442-7667, 15 (2).

Hidayah, Nurul, (2015), Pembelajaran Tematik Integratif di Sekolah Dasar, Jurnal Pendidikan dan Pembelajaran Dasar, 2 (1) Juni 2015p-ISSN 2355-1925.

Hidayat, Isnu (2019), 50 Strategi Pembelajaran Populer. Yogyakarta: Diva Press.

Muklis, Mohamad, (2012), Pembelajaran Tematik, Jurnal FENOMENA, IV (1), 2012.

Rahayu \& Tri H.S, (2018), Penerapan Model Pembelajaran Kooperatif Tipe Make a Match untuk Meningkatkan Aktivitas dan Hasil Belajar Siswa Kelas III pada 
Putri, A. Sapri, J., Lusa, $\mathrm{H}$.

Tema Harga Diri di SD Plalangan 02 Jember, Jurnal Ilmu Pendidikan Dasar, 6 (1) Januari 2018.

Shoimin, Aris, (2014), 68 Model Pembelajaran Inovatif dalam Kurikulum 2013. Yogyakarta: AR-RUZZ MEDIA.

Suini Ni W, (2019), Penerapan Metode Make a Match dalam meningkatkan Prestasi Belajar PKn pada Siswa Kelas V SDN 2 Pitera, Jurnal Ilmu-ilmu Pendidikan, e-ISSN 2623-1697, 17 (2) Desember 2019.

Taufiq, Agus dkk., (2012), Pendidikan Anak di SD. Tangerang Selatan: Universitas Terbuka. 